\title{
Lihasian yksi- ja kolmivaiheruokinnan vaikutus tuotantotuloksiin ja taloudellisuuteen
}

\author{
Samu Palander ${ }^{1)}$, Ida Nygård ${ }^{2}$ \\ 1) Seinäjoen ammattikorkeakoulu,PL 412,60101 Seinäjoki, samu.palander@seamk.fi \\ 2) Atria alkutuotanto, PL 900,60060 Atria,ida.nygård@atria.com
}

\section{TIIVISTELMÄ}

Sianlihantuotannon ympäristövaikutuksista merkittävimpiä ovat typpi- ja fosforipäästöt. Proteiinityppi ja fosfori ovat tärkeitä ravintoaineita sioille, mutta valkuais- ja kivennäisruokinnan epätarkkuus voi lisätä tuotannon ympäristökuormitusta. Lihasiat tuottavat sikatalouden typpi- ja fosforipäästöistä 60 $70 \%$, joten lihasian ruokinnalla on suuri vaikutus sikataloudesta aiheutuviin päästöihin. Mahdollisimman tarkka ruokinnansuunnittelu on avainasemassa ympäristövaikutusten minimoinnin näkökulmasta. Sian kasvaessa muuttuva ruokinta, vaiheruokinta, nähdään oleellisena keinona vähentää päästöjä, mutta myös parantaa tuotannon tehokkuutta ja kannattavuutta.

Tutkimuksen tarkoituksena oli selvittää, onko yksi- ja kolmivaiheruokintojen välillä eroa sikojen kasvussa, rehunmuuntosuhteessa ja lihakkuudessa, ja kumpi ruokintatapa siten on taloudellisempi. Tutkimusta varten suoritettiin käytännön ruokintakoe, jossa 504 risteytyslihasikaa kasvatettiin välitysporsaasta teuraspainoon. 1-vaiheruokinnan siat saivat samaa rehuseosta koko kasvatusajan. 3vaiheruokinnan sikojen ruokinnan vaihto alkukasvatusrehulta keskivaiheen rehulle tehtiin kasvatusviikolla 4, ja vaihto loppukasvatusrehulle kasvatusviikolla 8. Kasvu- ja teurastulokset analysoitiin regressio- ja varianssianalyysilla.

Tutkimuksessa havaittiin, että yksi- ja kolmivaiheruokintojen välillä ei juurikaan ollut eroja päiväkasvussa (1187 g vs. 1195 g) ja energiankäytössä lisäkasvukiloa kohti (22.2 MJ vs. 21,7 MJ). Kolmivaiheruokinnan sikojen lihaprosentin ja teuraspainon hajonnat olivat suurempia. Tutkimuksessa myös todettiin, että kolmivaiheruokinnan sikoja ei ehkä ole kannattavaa kasvattaa aivan teurastamon kärkipainovälin ylärajalle saakka. Tutkimuksen mukaan hieman matalammasta lihaprosentista huolimatta kolmivaiheruokinta vaikutti tulevan edullisemmaksi kuin yksivaiheruokinta.

Asiasanat: sika, ruokinta, lihaprosentti 


\section{Johdanto}

Vanhoissa ruokintasuosituksissa oli omat valkuais- ja aminohapposuositukset yksi-, kaksi- ja kolmivaiheruokintaan, mutta valkuaisarvojärjestelmän muutoksen jälkeen 2014 nykyisissä suosituksissa on valkuais- ja aminohapposuositukset vain kolmivaiheruokintaan (Luke 2018). Mm. ruotsalaisissa suosituksissa on aminohapposuosituksille elopainorajat n. $30 \mathrm{~kg}: \mathrm{n}$ välein ja tanskalaisissa vielä useampia painorajoja (Göransson ym. 2010, Tybrik ym. 2018).

Ruokinnan tarkentamisella pyritään sekä taloudellisuuteen että ympäristövaikutusten minimointin, ja siksi mahdollisimman hyvin tarvetta vastaavat ravintoainetasot ovat jatkuvan tutkimuksen kohteena (ks esim. Karhapää ym. 2014, Liu ym. 2017).

Sian kasvaessa sen rehun syöntimäärä lisääntyy, jolloin loppukasvatuksessa myös fosforipitoisuutta voidaan pienentää. Niukempi fosforin määrä loppukasvatuksessa voi vähentää lantaan erittyvän fosforin määrää ja rehufosfaatin käyttötarvetta lihasian kasvun ja liikuntakyvyn kärsimättä (Partanen ja Volanto 2007, Partanen ym. 2010).

Tutkimuksessa haluttiin selvittää yksi- ja kolmivaiheruokinnan eroja duroc-kolmiroturisteyssioilla tilaolosuhteissa ja samalla testata tuotannollisella tilalla tehtävän lihasikojen ruokintatutkimuksen mahdollisuuksia. Oletuksena oli, että kolmivaiheruokinta on edullisempi ruokintastrategia kuin yksivaiheruokinta, koska kolmivaiheruokinnassa valkuaistasoja muutetaan sian kasvaessa ja ne vastaavat paremmin kunkin kasvatusvaiheen valkuaistarvetta. Yksivaiheruokinnassa porsas saa lähtökohtaisesti valkuaisruokintasuosituksiin nähden liian vähän valkuaista alkukasvatuksessa ja loppuvaiheessa liikaa. Koska valkuainen on sian ruokinnassa kallein komponentti ja sian ruokintakustannus voi olla jopa $65 \%$ muuttuvista kustannuksista, on sikatalouden heikentyneen kannattavuuden myötä tärkeä löytää kohteet, joista muuttuvia kustannuksia voidaan alentaa.

\section{Aineisto ja menetelmät}

\section{Sikala}

Sikala, jossa koe suoritettiin, on A-Tuottajat Oy:n sopimustuotantotila ja toimii osana normaalia sianlihan tuotantoketjua. Tilalla on varattu koetoiminnalle kolme osastoa, johon mahtuu yhteensä 540 lihasikaa. Koeosastoissa on kaksinkertainen ruokintalinjasto siten, että osastossa oleviin karsinoihin on mahdollista jakaa kahta eri rehuseosta. Jokaisessa osastossa on 16 karsinaa ja kahdeksan ruokintaventtiiliä. Yhden venttiilin ruokkimat kaksi karsinaa kussakin osastossa on varattu sairaskarsinoiksi. Kuhunkin karsinaan sijoitettiin 12 sikaa, joten yksi venttiili ruokkii 24 sikaa.

\section{Rehut ja ruokinta}

Kokeessa oli mukana kolme sikalaosastoa, ja porsaat jaettiin osastoihin siten, että toinen puoli osastosta oli yksivaiheruokinnalla ja toinen puoli kolmivaiheruokinnalla, jolloin porsaiden kasvatusolosuhteet olivat samanlaiset. Porsaat jaettiin karsinoihin koon mukaan, ja jokaisessa karsinassa oli suurin piirtein sama määrä leikko- ja imisäporsaita. Lopulliseen kokeeseen tuli yksivaiheruokintaan 264 porsasta ja kolmivaiheruokintaan 240 porsasta.

Porsaille annettiin heti tulopäivästä alkaen ruokintaryhmän mukaista rehua. Rehu jaettiin porsaille viisi kertaa päivässä automaattisesti liemiruokkijan tietokoneelle asetetun ruokintakäyrän mukaisesti. Rehua lisättiin tai vähennettiin päivittäin syönnin mukaan siten, ettei kaukalossa ruokittaessa ollut edellisen jakokerran rehua jäljellä. Ruokinta pyrittiin rajoittamaan enintään $3.0 \mathrm{~kg}$ :aan kuiva-ainetta päivässä. 
Molempien koeruokintojen resepteissä pääraaka-aine oli tilalla viljelty ohra ja vehnä. Lisävalkuaislähteenä oli ohravalkuaisrehu, ja seosta täydennettiin tiivisteellä, joka sisälsi muun muassa kivennäisaineita, vitamiineja ja puhtaita aminohappoja). Taulukossa 1 on esitetty rehuseosten komponenttien osuudet. yksivaiheruokinnan siat saivat samaa rehuseosta koko kasvatusajan. Kolmivaiheruokinnassa vaihto alkukasvatusrehulta keskivaiheen rehulle tehtiin kasvatusviikolla 4, ja vaihto loppukasvatusrehulle tehtiin kasvatusviikolla 8. Siat ruokittiin loppukasvatusrehulla teurastukseen saakka.

Taulukko 1. Rehuseosten reseptien raaka-aineet (\% kuiva-aineesta).

\begin{tabular}{lcccc}
\hline & yksivaiheruokinta & $\begin{array}{c}\text { vaiheruokinta, } \\
\text { alkukasvatus }\end{array}$ & $\begin{array}{c}\text { vaiheruokinta, } \\
\text { keskivaihe }\end{array}$ & $\begin{array}{c}\text { vaiheruokinta, } \\
\text { loppukasvatus }\end{array}$ \\
\hline Ohra & 63.75 & 55.84 & 66.03 & 74.09 \\
Vehnä & 4.46 & 8.02 & 4.47 & 2.51 \\
Ohravalkuaisrehu & 22.51 & 25.47 & 20.42 & 15.67 \\
A-Mix ${ }^{1}$ & 9.30 & 10.66 & 9.08 & 7.73 \\
\hline
\end{tabular}

${ }^{1}$ Kaupallinen lysiinipitoinen tiiviste OVR-ruokintaan (A-Rehu Oy, Seinäjoki)

Rehuseosten laskennalliset koostumukset on esitetty taulukossa 2. Valkuais-, aminohappo- ja fosforitasot perustuivat täydennysrehun valmistajan (A-Rehu Oy) suosituksiin.

Taulukko 2. Rehuseosten laskennallinen energia-arvo ja ravintoainekoostumus.

\begin{tabular}{|c|c|c|c|c|}
\hline & yksivaiheruokinta & $\begin{array}{c}\text { vaiheruokinta, } \\
\text { alkukasvatus }\end{array}$ & $\begin{array}{l}\text { vaiheruokinta, } \\
\text { keskivaihe }\end{array}$ & $\begin{array}{l}\text { vaiheruokinta, } \\
\text { loppukasvatus }\end{array}$ \\
\hline $\mathrm{NE}_{\mathrm{k}} \mathrm{MJ} \mathrm{kg}^{-1} \mathrm{KA}$ & 10.9 & 10.8 & 10.9 & 10.9 \\
\hline $\mathrm{SRV}_{\mathrm{k}} \mathrm{g} \mathrm{MJ}^{-1}$ & 14.2 & 15.0 & 13.6 & 12.3 \\
\hline Lysiini (SID) $\mathrm{g} \mathrm{MJ}^{-1}$ & 0.91 & 1.01 & 0.88 & 0.77 \\
\hline Treoniini (SID) $\mathrm{g} \mathrm{MJ}^{-1}$ & 0.61 & 0.66 & 0.59 & 0.53 \\
\hline Met+Kys (SID) g MJ & 0.59 & 0.62 & 0.57 & 0.53 \\
\hline Sulava fosfori $\mathrm{g} \mathrm{MJ}^{-1}$ & 0.58 & 0.61 & 0.55 & 0.50 \\
\hline Kalsium $\mathrm{g} \mathrm{MJ}^{-1}$ & 0.78 & 0.90 & 0.74 & 0.65 \\
\hline
\end{tabular}

Rehunkulutustiedot kerättiin joka kasvatusviikolta, ja rehunkulutus kirjattiin ylös venttiilikohtaisesti. Venttiileittäin kerätty tieto laskettiin yhteen ja koottiin viikon kokonaisrehunkulutukseksi.

\section{Punnitukset ja määritykset}

Porsaita punnittiin tutkimuksen aikana kahdesti. Ensimmäinen punnitus tehtiin kokeen alussa, jolloin kaikki porsaat punnittiin karsinoittain. Toinen punnitus tehtiin kasvatusviikolla 7, ja tällöin jokaisesta osastosta punnittiin satunnaisesti valitun kolmen venttiilin (karsinaparin) siat karsinoittain molemmista ruokintaryhmistä. Osastoilla tehtiin yksi harvennus kasvatusaikana, jolloin teuraaksi lähtevien eläinten paino arvioitiin silmämääräisesti niin, että se vastaa mahdollisimman hyvin teurastamon kärkipainoväliä (sian teuraspainoa, josta teurastamo maksaa korkeimman hinnan). Kärkipainovälin saavuttaneet siat lähetettiin teuraaksi. Harvennus tehtiin kasvatusviikolla 11. Loput siat lähetettiin teuraaksi kerralla riippumatta painosta kasvatusviikon 13 jälkeen. Siat tatuoitiin ruokintaryhmäkohtaisesti ja teurastettiin Atrian teurastamolla Seinäjoella. Kaikista sioista määritettiin teuraspaino ja lihaprosentin laskentaa varten tarvittavat tiedot (Autofom). 


\section{Tulokset ja niiden tarkastelua}

\section{Tutkimukseen osallistuneet eläimet}

Yksivaiheruokinnan sioista teuraaksi tuli 249 ja 3-vaiheruokinnan sioista 227. Sikojen yleiskunto oli koko kokeen ajan hyvä. Kokeen aikana yksivaiheruokinnan sioista kuoli tai siirrettiin sairaskarsinaan 9 sikaa ja kolmivaiheruokinnan sioista 6 sikaa, eikä näitä ole huomioitu kokeen lopputuloksissa. Kuolleiden ja sairastuneiden sikojen määrä vastasi tilan tavallista poistomäärää tuotannossa.

\section{Elopaino, kasvu ja rehunmuuntosuhde}

Alkupunnituksessa molempien ryhmien keskipaino karsinoittain määritettynä oli $30.0( \pm 0.86) \mathrm{kg}$. Taulukoissa 3 on esitetty molempien ruokintaryhmien elopaino, päiväkasvu ja rehumuuntosuhde kasvatusviikkojen 1 ja 7 välillä kolmessa satunnaisessa karsinaparissa. Kolmiroturisteytysten kasvu oli alkuvaiheessa nopeaa (lähes $1200 \mathrm{~g} \mathrm{~d}^{-1}$ ) ja rehunmuuntosuhde hyvä.

Taulukko 3. Yksivaihe- ja komivaiheruokintaa edustavien näytekarsinoiden sikojen kasvu ja rehuenergian kulutus kasvatusviikoilla $1-7$.

\begin{tabular}{lccc}
\hline & 1-vaihe & 3-vaihe & SEM \\
\hline elopaino & 87.33 & 87.87 & 0.716 \\
päiväkasvu & 1186 & 1195 & 11.1 \\
RMS MJ/kg lisäkasvua & 22.1 & 21.7 & 0.20 \\
\hline
\end{tabular}

Taulukossa 4 on esitelty kasvutulokset molemmille kasvatuserille koko kokeen aikana. Ruokintastrategian vaikutus loppupainoon teurastusiässä ja päiväkasvuun jäi epävarmaksi $(0.05<\mathrm{P}>$ $0.10)$, mutta kolmivaiheruokinnan sikojen teuraspaino oli jonkin verran korkeampi $(\mathrm{P}<0.05)$.

Tuotannossa on tavoiteltu lihasikojen kasvatuksessa 25.9-28.0 MJ:n energiankulutusta lisäkasvu-kg:a kohti. Kokeessa kolmivaiheruokinnan sikojen rehunmuuntosuhde näin ilmaistuna oli $27.7 \mathrm{MJ} \mathrm{kg}^{-1}$ lisäkasvua ja yksivaiheruokinnan sioilla niukasti parempi $27.3 \mathrm{MJ} \mathrm{kg}^{-1}$ lisäkasvua.

Mooren ym. (2016) tutkimuksessa verrattiin erilaisia ruokintastrategioita elopainoltaan $30-100-$ kiloisilla sioilla. Tutkimuksessa ei havaittu eroa syönnissä ja rehunmuuntosuhteessa ruokintatapojen (yksivaihevaiheruokinta, kolmivaiheruokinta ja viikoittain vaihtuva rehuseos) välillä. Myöskään O’Connell ym. (2005) eivät havainneet eroja sikojen kasvussa verrattaessa yksivaiheruokintaa viisivaiheruokintaan.

\section{Teurastulokset}

Lihaprosentti on esitetty taulukossa 4. Kolmivaiheruokinnan sikojen lihaprosentti oli 0.6 prosenttiyksikköä matalampi kuin 1-vaiheruokinnan sioilla $(\mathrm{P}<0.05)$. Moore ym. (2016) raportoivat paremmasta teurasprosentista ja vähäisemmästä rasvoittumisesta kolmivaiheruokinnassa. Tässä kokeessa kolmivaiheruokinnan sioilla oli enemmän hajontaa teuraspainossa ja lihaprosentissa kuin yksivaiheruokinnan sioilla. Kolmivaiheruokinnan sikojen lihaprosentit näyttivät laskevan lopputyhjennyksessä verrattuna harvennukseen, mutta yksivaiheruokinnan sikojen lihaprosentissa vastaavaa muutosta ei ollut.

Kärkipainovälin sioista tutkittiin regressioanalyysillä, riippuuko lihaprosentti teuraspainosta, mutta ja mallin selitysaste oli lähellä nollaa, eikä regressiokerroin ei ollut merkitsevästi nollasta poikkeava. 
Kokeen sikoja ei sukupuolilajiteltu karsinoittain, eikä tuloksista selviä, lähtikö harvennuksessa enemmän leikkoja kuin imisiä teuraaksi. Jos näin on, lopputyhjennyksessä imisien määrä oli vastaavasti suurempi. Yksivaiheruokinnalla valkuaistaso seoksessa on koko ajan sama ja korkeampi kuin kolmivaiheruokinnan loppukasvatusrehussa. Tästä voisi johtua, että yksivaiheruokinnan imisät saivat lopussa enemmän valkuaista, eivätkä näin ollen rasvoittuneet yhtä herkästi. Leikot kasvoivat nopeammin myös O’Connellin ym. (2005) tutkimuksessa, ja imisien ja leikkojen kyky käyttää lisävalkuaista eri toisistaan. Suurehkoa hajontaa kolmivaiheruokinnan lopputyhjennyksen lihaprosentissa voi selittä myös se, että harvennuksen jälkeen karsinaan jääneet leikot söisivät edelleen enemmän kuin imisät. Leikkojen syödessä enemmän loppukasvatusvaiheessa ne myös rasvoittuisivat enemmän rajallisen lihaksenkasvukyvyn takia. Kolmivaiheruokintaa tulisikin tutkia sukupuolilajitelluilla sioilla.

Mikäli lopputyhjennyksen sioista suurin osa oli imisiä, voisi niiden lihaprosenttia lopputyhjennykseen saada nostettua antamalla rehua vapaammin tai nostamalla hieman loppukasvatusrehuseoksen valkuaispitoisuutta. Punaisen lihan tuottokyky joka tapauksessa laskee sian kasvaessa, joten ruokinnan rajoittamisella loppukasvatusvaiheessa voidaan rajoittaa etenkin leikkojen rasvoittumista, joten ruokinnan lisääminen sopisi vain imisille. Rehuannoksen lisääminen ja valkuaisen lisääminen nostavat rehukustannusta, mutta parantunut lihaprosentti voisi kompensoida tätä.

Taulukko 4. Yksi- ja kolmivaiheruokinnan sikojen kasvu koko kokeen ajalta ja teurastulokset.

\begin{tabular}{lcccc} 
& 1-vaihe $^{1}$ & 3-vaihe & SEM & P \\
\hline Loppuelopaino $^{3}$ & 127 & 129 & 9.3 & 0.062 \\
Teuraspaino & 94.7 & 95.9 & 6.69 & 0.049 \\
Päiväkasvu & 1104 & 1125 & 101.9 & 0.062 \\
Lihaprosentti & 57.5 & 56.9 & 2.85 & 0.015 \\
\hline
\end{tabular}

${ }^{1} \mathrm{n}=249,{ }^{2} \mathrm{n}=227,{ }^{3}$ laskennallinen (tyypillisen teurasprosentin mukaan)

\section{Taloudellisuus}

Yksivaiheruokinnan rehukustannus oli kärkipainovälin sioilla 50.48 euroa/sika, kun se kolmivaiheruokinnalla oli 47.80 euroa/sika. Lisäkasvukiloa kohti ruokintakustannus oli yksivaiheruokinnassa 0.544 euroa ja kolmivaiheruokinnan sioilla 0.517 euroa. On kuitenkin huomattava, että heikompi lihaprosentti vaikuttaa tilityshintaan negatiivisesti. Mooren ym. (2016) tutkimuksessa yksivaiheruokinta tai viikoittain vaihtuva ruokinta olisivat edullisempia kuin kolmivaiheruokinta johtuen matalammasta lysiinin kulutuksesta. Toisaalta, kun lihakkuudesta maksetaan lisähintaa, komivaiheruokinnan edut tulivat esiin.

\section{Johtopäätökset}

Kolmivaiheruokinta oli 2.68 euroa/sika edullisempi kuin yksivaiheruokinta. Kokeen siat kasvoivat molemmilla ruokintatavoilla yhtä hyvin, ja rehumuuntosuhde oli molemmilla hyvä, mutta kolmivaiheruokinnan sikojen rehukustannus tuotettua lihakiloa kohti oli pienempi. Myös laskennallinen rehuvalkuaisen kulutus kasvatuskaudella ja lisäkasvukiloa kohti olivat matalampia kolmivaiheruokinnan sioilla.

Tutkimuksen perusteella kolmivaiheruokinnan sikoja ei kannattaisi kasvattaa aivan kärkipainorajan ylärajalle. 11 viikon harvennuksessa kolmivaiheruokinnan sioilla oli parempi lihaprosentti, mutta lopputyhjennyksessä se oli huonompi kuin yksivaiheruokinnalla. Kokeessa porsaita ei lajiteltu karsinoihin sukupuolen mukaan, eikä sioista mainittu harvennuksen tai lopputyhjennyksen yhteydessä sukupuolta. Todennäköisesti ensimmäisessä harvennuksessa lähti pääasiassa paremmin syöviä ja 
kasvaneita leikkoja teuraaksi ja lopputyhjennyksessä imisiä ja toisaalta mukana heikommin kasvaneita sikoja, mikä voi selittää lopputyhjennyksen suurempaa lihaprosentin hajontaa.

\section{Kirjallisuus}

Göransson, L., Lindberg, J. E. \& Borling J. 2010. Aminosyror. Sveriges lantbruksuniversitet. Viitattu 20.12.2019. https://www.slu.se/globalassets/ew/org/inst/huv/bilder-fran-gamla-webben/verk-tyg/fodermedel-och-naringsrektill-gris/naringsrekommendationer/naringsre-kommendation_aminosyror_2010_2.pdf

Kyntäjä, S., Siljander-Rasi, H. \& Niemi, J. 2.8.2016. Uuden valkuaisjärjestelmän toimivuus kolmirotusioilla. Suomen maataloustieteellisen seuran tiedote 33: https://doi.org/10.33354/smst.75178

Liu, S., Ni, J.-Q., Radcliffe, J.S. \& Vonderohe, C.E. 2017. Mitigation of ammonia emissions from pig production using reduced dietary protein with amino acid supplementation. Biosource Technology 233: 200-208.

https://doi.org/10.1016/j.biortech.2017.02.082

Luke 2018. Rehutaulukot ja ruokintasuositukset. Luonnonvarakeskus. Viitattu 22.12.2019.

http://www.luke.fi/rehutaulukot.

Moore, K.L., Mullan, B.P. \& Kim, J.C. 2016. An evaluation of the alternative feeding strategies, blend feeding, three-phase feeding or a single diet, in pigs from 30 to 100kg liveweight. Animal Feed Science and Technology 216: 273-280. https://doi.org/10.1016/j.anifeedsci.2016.04.001

O'Connel, M.K., Lynch, P.B. \& O'Doherty, J.V. 2005. A comparison between feeding a single diet or phase feeding a series of diets, with either the same or reduced crude protein content, to growing finishing pigs. Animal Science 81: 297-303. https://doi.org/10.1079/ASC50310297

Partanen, K. \& Volanto, P. 2007. Isoille lihasioille riittää vähempikin fosfori. Maaseudun tiede. http://urn.fi/URN:NBN:fi-fe2015103015542

Partanen, K., Karhapää, M., Särkijärvi, S., Palander, S., Tuori, M. \& Voutila, L. 2010. Sikojen

ruokintasuositukset ja fytaasin vaikutus fosforin sulavuuteen. Maatalouden tutkimuskeskus: Rehuarvoseminaari. https://portal.mtt.fi/portal/page/portal/Rehutaulu-kot/Tietoa_palvelusta1/Rehuarvosemi-

naari_2010/824ECB159B32D9ADE040A8C0023C478B

Tybrik, P., Sloth, N.M., Kjeldsen, N. \& Shooter, L. 2019. Danish nutrient standards. 29th edition. Seges Pig Research Center. https://pigresearchcentre.dk/Research-results 